\title{
May telephone surveys provide reliable public health surveillance data for municipalities? Mode effects differ between categories of questions. The HUNT Study, Norway
}

\author{
Mattias Tagseth ${ }^{1}$, Erik R. Sund ${ }^{1}$, Göran T.A. Hallman ${ }^{2}$, Jostein Holmen ${ }^{1}$, Kyrre Kvistad ${ }^{3}$, \\ John Tore Vik ${ }^{4}$ and Steinar Krokstad ${ }^{1}$ \\ 1) HUNT Research Centre, NTNU - Norwegian University of Science and Technology \\ 2) Health policy department, Region of Jämtland Härjedalen \\ 3) Nord-Trøndelag County Council \\ 4) Sør-Trøndelag County Council \\ Correspondence: Mattias Tagseth, mattias.tagseth@ntnu.no
}

\begin{abstract}
Background: Availability of data on health and its determinants at the local area level is a prerequisite for developing interventions and public health campaigns locally. Collecting self-reported data by means of telephone interviews may rapidly provide relevant data. The reliability of such data may be questioned. In this study, we sought to compare exact similar questions addressed by a recent telephone survey with a previous large scale and very comprehensive population health survey (The Nord-Trøndelag Health Study 2006-08 - HUNT3), conducted a few years earlier in the same geographical region. This was done in order to examine the reliability of telephone interviews as a method to provide data on health and determinants to enable municipal authorities to get a sufficient overview.

Methods: One rural and one urban municipality covered by HUNT3 using paper questionnaires were resurveyed through computer assisted telephone interviews. The weighted results for 34 dichotomized variables were compared using chi square tests.

Results: The comparison of results between the rural and the urban samples and HUNT3 involved 68 chi square tests, 25 of which (38\%) displayed significant differences. The ability of the telephone survey to replicate the results from HUNT3 was only moderate, but with differences between survey themes. Comparability was poor for adverse life events and mental health factors, fair for behavioural and risk factors, and skewed for general health and life satisfaction. The replication was good for reports on the less sensitive and subjective theme of cultural participation.

Conclusion: The comparability of the data differed between themes. The differences may be ascribed to mode effects and to some extent the time lag between the surveys. Because replicability on issues that may be more embarrassing or stressful to recall appears to be poorer, and the more subjective self-assessments of health and well-being appear skewed, it is reasonable to conclude that there is an interviewer effect in the telephone survey. The use of a questionnaire through mail or web to monitor public health in municipalities should be considered as an alternative.
\end{abstract}

This is an open access article distributed under the Creative Commons Attribution Licence, which permits unrestricted use, distribution, and reproduction in any medium, provided the original work is properly cited.

\section{BACKGROUND}

The Norwegian health care reform, known as the Coordination Reform, decentralised responsibilities for health care to the municipal level from 2011, and increased the emphasis on preventive health care. The reform was implemented in order to counter the challenges to economic sustainability from demographic changes and changes in epidemiology [1]. Under the Public Health Act of 2011 [2] and associated regulations [3], Norwegian municipalities (and counties) are required to maintain an overview of public health as a basis for health care planning and long-term efforts in public health. Every four years, each municipality is to work out an overview report as part of the basis for its planning strategy. Access to data on health and health determinants at the local area level is a prerequisite for developing targeted interventions and public health campaigns locally. In a knowledge-based approach to public health, there is a demand for data on lifestyle (habits), risk factors and health that can be broken down to regional and local overviews. Access to better data would improve the conditions for implementing targeted measures, and make it possible to evaluate the effect of these measures undertaken by municipalities and counties as intended in the reform [4].

While data from comprehensive regional health surveys are utilised to some extent in municipal planning in regions where they are available and recent, conducting a full-scale public health survey is not usually feasible for municipal planning purposes. Among the several statistical sources available today, data from registries like the Cancer Registry of Norway, the Norwegian Prescription Database and others are broken down and used in the municipal overview documents. The surveys among youth, conducted with coverage 
for all or selected schools, also provide useful information for public health overviews. However, the samples for the national health surveys are limited, and results cannot be broken down to small geographical areas. The available registry and survey data constitute an inadequate basis for planning, as they can be outdated, not sufficiently valid for the purpose, and provide too limited information about self-assessed health, health behaviour and risk factors. There is thus reason to consider several available options for sample surveys in municipalities. Either the commonly used methods rely on an interviewer to administer questions through face-to-face interviews or phone interviews, or they rely on self-completion by respondents. Self-completion questionnaires can be administered as pen-and-paper questionnaires, often by mail, or as computerized questionnaires that can be administered through the web. Face to face interviewing may be desirable, and has been regarded as a golden standard survey mode [5]. It is to some extent used and thus within reach for health surveys, but it would be prohibitively expensive for municipal planning purposes.

Collecting self-reported data by means of telephone interviews may provide a rapid and convenient source of data that enable local authorities to get sufficient overview of public health if combined with data from registries and national statistics. However, the reliability of such data may be questioned since responses collected by different modes of data collection may differ. Brøgger et al. [6] compared telephone and postal survey modes on respiratory symptoms and risk factors, by resurveying $1 \%$ of a survey sample by telephone with a lag of six months. A moderate effect of survey mode was found, with effects depending on the specific questions asked. Christensen et al. [7] examined self-administered questionnaires from two general population health surveys with identical questions to those of an interview-based survey through multiple logistic regression. Here, factual questions with simple answer categories were found to be more comparable across modes than indicators based on questions that involved assessments that are more subjective. Tipping et al. [8] compared data sets from face-to-face interviews and self-completion questionnaires and selfcompletion questionnaires administered in different contexts. Weights were applied to the results before they were compared by chi-square tests and two tailed t-tests. The results indicate that some data collected through the two modes can be combined safely, but differences likely to reflect mode factors were present. Differences appeared especially in the collection of complex data, while answers to questions with simple answer categories were more comparable. Feveile et al. [9] conducted a randomised trial of mailed questionnaires versus telephone interviews in Denmark. Responses reporting health behaviour were analysed for extreme responses, but no significant differences found. In the majority of the mode sensitive self- assessments of health and well-being, a more positive reporting was identified among telephone respondents through chi-square tests. Research on mode effects on sensitive issues tends to emphasise the presence or absence of an interviewer as a significant factor in affecting mode-related bias [10,11].

In the present study, we sought to compare exact similar questions addressed by a recent telephone survey (hereafter TS) with a previous large scale and very comprehensive population health survey, the Nord-Trøndelag Health Study in 2006-2008 (HUNT3), conducted a few years earlier in the same geographical region. The objective of this study was to examine the reliability of telephone interviews as a method to provide data on health and determinants to enable municipal authorities to monitor public health.

\section{METHODS}

\section{Data and participants}

The HUNT Study, which is an acronym for The NordTrøndelag Health Study in the Norwegian language, is a large population database for medical and health research [12]. Three health surveys of the entire adult population in a Norwegian county have been conducted: HUNT1 in 1984-1986, HUNT2 in 1995-1997 and HUNT3 in 2006-2008. HUNT4 is in the data collection phase from 2017 to 2019 . The HUNT Study now includes large total population based cohorts covering about 125000 participants. Data were collected through questionnaires and interviews, along with clinical measurements and biological samples. The major health surveys conducted in Norway, including the Tromsø Study [13] and HUNT [12], have thus far chosen self-completion questionnaires administered on paper in the collection of data on self-reported health, behavioural and risk factors. Participation rates have been steadily declining, from $88 \%$ in HUNT1, to $71 \%$ in HUNT2 and lastly 54\% overall in HUNT3. Whereas minor participation bias was reported in HUNT1 and HUNT2, a nonparticipation study conducted after HUNT3 found non-participants to have somewhat lower socioeconomic status, higher mortality and higher prevalence of several chronic diseases than the participants in HUNT3 [14]. The Regional Committee for Medical and Health Research Ethics (REC) has approved the HUNT Study, and all participants have provided written consent. The TS was approved by Regional Committee for Medical and Health Research Ethics (REK midt, 2013/1365/REK midt).

The telephone health survey constitutes one of four work packages in a cross-country collaboration project between Sweden and Norway on Political Decisions on Determinants - Research Area (PODD-RA). Eight municipalities were selected for the survey: three in the Swedish county of Jämtland, three in the county of Sør-Trøndelag and two in the county of NordTrøndelag in Norway. The two municipalities in the 
Nord-Trøndelag County, one rural with a population of 4122 persons (2010) and the other a small town with a population of 21080 (2010), have previously been surveyed in HUNT3. Questions in the TS were based on questionnaires from HUNT3 (Appendix), thus allowing comparability for these two municipalities. A total of 29 questions, with a number of sub-questions, were asked the respondents, rendering a total of 61 variables, and 34 of these variables were comparable with HUNT3.

Sentio Research Norge A/S, a commercial company specialized in doing telephone surveys, performed the data collection in the TS. The interviews took place in the last two weeks of November 2013, and each lasted less than 15 minutes. The need for an improved overview of the health of the inhabitants in the municipality, and testing whether telephone interviews could be used towards that end were mentioned as objectives in an introduction to the interviews. Further, it was explained that the survey was undertaken by the NordTrøndelag County Council, the Sør-Trøndelag County Council and the HUNT Research Centre at the Norwegian University of Science and Technology. The respondents also received information about how to contact available medical staff, should they feel a need for it. Information about the survey was also posted in advance on the websites of the surveyed municipalities.

Sample sizes of 400 adults out of 16750 (2013) for the small town municipality and 200 adults out of 3259 (2013) for the rural municipality were determined pragmatically, and with an eye to our budget. It was seen as favourable if sample sizes were possible to replicate within the means of Scandinavian municipalities, and a smaller sample size was chosen for small municipalities. A random list of private telephone subscribers controlled for the composition of mobile phones and landlines was generated. A sampling procedure was applied to achieve a stratified sample, controlled for the population composition in terms of age group and gender as of 2013 for each municipality. An automated calling system pulled and dialled new numbers randomly from this list until the targets for age and sex categories were reached. No repeat call attempts were made, so that those members of the sample that did not pick up the phone were substituted using reserve numbers from the same random list of subscribers until the targeted number of interviews had been made in each municipality. Some $81 \%$ of the numbers called were replaced with numbers from the initial sample. A total of 1000 individuals and 1300 individuals participated in Sweden and Norway respectively. With the $18 \%$ bad numbers in the list of randomly selected landline and mobile telephone subscribers excluded, the participation rate in Norway was $23 \%$. The HUNT3 participation rate in the two municipalities was $55.9 \%$. The cost of the TS was $c$ $165 \mathrm{NOK}(£ 18)$ per interview, corresponding to $c$ 33000 NOK $(3600 £)$ for a small municipality and 66000 NOK $(7200 £)$ for a larger.

\section{Analysis}

All variables were dichotomized and comparisons were made based on weighted estimates taken from HUNT3 and the TS. These weights correct for unequal selection probabilities and the effects of differential non-response. The surveys were weighted separately using the same weighting procedure, which corrected for differential responses by age and sex in each municipality. Both samples were weighted with reference to the composition of the population in each municipality at a date at a midpoint between the surveys. Both samples are thus similar in terms of age and sex profiles in each municipality. Item non-response was negligible in the TS, but more noticeable in the HUNT3 survey. The survey estimates are based on valid estimates only and no attempt has been made to impute missing data. For each comparison, the missing responses were excluded. The analyses were carried out using chi-square tests, and P-values $<0.05$ (two-tailed) were considered to be significant. The analysis was done in SPSS version 23 .

\section{RESULTS}

\section{Descriptive}

Table 1 shows the relative distribution of basic characteristics for HUNT3 and the rural and the urban sample drawn for the TS.

\section{General health, pain and life satisfaction}

Identical questions were asked of general health, bodily pain and general life satisfaction in the TS and in HUNT3. As shown in table 2, the urban TS displayed a significantly lower frequency of poor selfrated health, of long standing limiting illness and of current bodily pain of more than six months' duration than found in HUNT3. The results for these questions did not differ significantly between the rural TS sample and HUNT3. Regarding the experience of strong bodily pain during the last four weeks, the differences were not significant. The proportion rating their own general life satisfaction as poor did not vary significantly between HUNT3 results and the two TS samples.

Table 1. The relative distribution of basic characteristics for the Nord-Trøndelag Health Study in 2006-2008 (HUNT3) and the rural and the urban sample drawn for the telephone survey (TS).

\begin{tabular}{llcccc}
\hline Urban municipality & & TS & N & HUNT3 & N \\
\hline Age in years (mean) & & 51.1 & 400 & 50.7 & 8788 \\
Sex (\%) & Males & 49.8 & 199 & 49.7 & 4369 \\
& Females & 50.3 & 201 & 50.3 & 4419 \\
\hline Rural municipality & & TS & \multicolumn{1}{c}{ N } & HUNT3 & N \\
\hline Age in years (mean) & & 49.6 & 200 & 49.2 & 1412 \\
& Males & 51.0 & 102 & 50.8 & 718 \\
& Females & 49.0 & 98 & 49.2 & 694 \\
\hline
\end{tabular}


Table 2. General health, pain and life satisfaction measured in the Nord-Trøndelag Health Study in 2006-08 (HUNT3) and the rural and urban sample drawn for the telephone survey (TS). Differences significant beyond $5 \%$ are emphasized in italics.

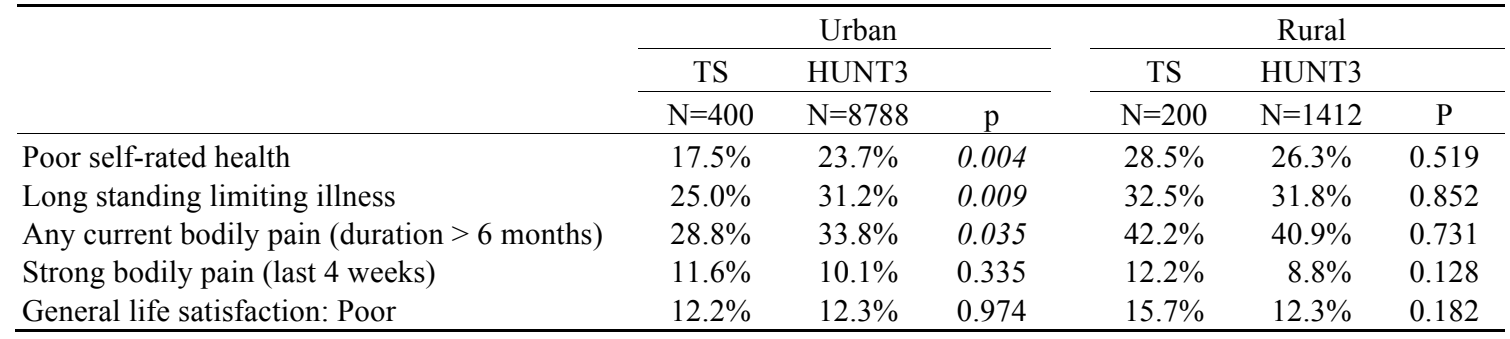

Table 3. Lifestyle, behaviour and risk factors measured in the Nord-Trøndelag Health Survey in 2006-08 (HUNT3) and the rural and urban sample drawn for the telephone survey (TS). Differences significant beyond $5 \%$ are emphasized in italics.

\begin{tabular}{|c|c|c|c|c|c|c|}
\hline & \multicolumn{3}{|c|}{ Urban } & \multicolumn{3}{|c|}{ Rural } \\
\hline & TS & HUNT3 & & TS & HUNT3 & \\
\hline & $\mathrm{N}=400$ & $\mathrm{~N}=8788$ & $\mathrm{p}$ & $\mathrm{N}=200$ & $\mathrm{~N}=1412$ & $\mathrm{P}$ \\
\hline Smoking & $14.0 \%$ & $16.0 \%$ & 0.277 & $21.0 \%$ & $21.2 \%$ & 0.936 \\
\hline Frequent alcohol use (last year) & $19.8 \%$ & $16.2 \%$ & 0.057 & $10.6 \%$ & $15.3 \%$ & 0.078 \\
\hline High glucose (any proven) & $9.2 \%$ & $7.0 \%$ & 0.083 & $12.5 \%$ & $7.6 \%$ & 0.018 \\
\hline Blood pressure medication (current/ any) & $22.6 \%$ & $16.7 \%$ & 0.002 & $26.5 \%$ & $18.8 \%$ & 0.011 \\
\hline Overweight (BMI $\geq 25)$ & $52.0 \%$ & $62.9 \%$ & 0.000 & $56.3 \%$ & $66.9 \%$ & 0.004 \\
\hline Obesity (BMI $\geq 30)$ & $13.9 \%$ & $19.4 \%$ & 0.008 & $11.1 \%$ & $23.8 \%$ & 0.000 \\
\hline
\end{tabular}

Table 4. Adverse life events last year or ever measured in the Nord-Trøndelag Health Study in 2006-08 (HUNT3) and the rural and urban sample drawn for the telephone survey (TS). Differences significant beyond $5 \%$ are emphasized in italics.

\begin{tabular}{|c|c|c|c|c|c|c|}
\hline & \multicolumn{3}{|c|}{ Urban } & \multicolumn{3}{|c|}{ Rural } \\
\hline & TS & HUNT3 & & TS & HUNT3 & \\
\hline & $\mathrm{N}=400$ & $\mathrm{~N}=8788$ & $\mathrm{P}$ & $\mathrm{N}=200$ & $\mathrm{~N}=1412$ & $\mathrm{P}$ \\
\hline Experienced death of relatives (last year) & $14.8 \%$ & $10.1 \%$ & 0.003 & $16.5 \%$ & $9.1 \%$ & 0.001 \\
\hline Been in a life threatening situation (last year) & $1.8 \%$ & $3.4 \%$ & 0.071 & $2.0 \%$ & $3.5 \%$ & 0.258 \\
\hline Marital/cohab. breakup (last year) & $6.5 \%$ & $10.2 \%$ & 0.017 & $6.5 \%$ & $12.8 \%$ & 0.011 \\
\hline Suppressed/humiliated (ever) & $12.2 \%$ & $12.3 \%$ & 0.974 & $26.0 \%$ & $19.8 \%$ & 0.044 \\
\hline Troubled childhood & $17.3 \%$ & $13.6 \%$ & 0.036 & $20.5 \%$ & $13.0 \%$ & 0.004 \\
\hline
\end{tabular}

\section{Lifestyle, behaviour and risk factors}

Several lifestyle-, behavioural and risk factors were examined by asking the same questions, with results shown in table 3 . The prevalence of both overweight and obesity found in HUNT3 was significantly higher than in the urban and rural TS. HUNT3 included clinical examinations in addition to questionnaires, and obesity and overweight were not self-reported as in the TS, but calculated from measurements of height and weight. Self-reported use of blood pressure medication was significantly higher in the TS than in HUNT3 for both TS samples. The self-reported prevalence of high glucose was higher in the rural TS sample than found in HUNT3, but not significantly higher in the urban TS. Reported smoking and frequent alcohol consumption was not significantly different from HUNT3 in the two TS samples.

\section{Psychological factors}

The psychological risk factors from several possible adverse life events were examined (table 4), as well as several mental health indicators. The proportion recalling having experienced the death of relatives during the last year was significantly higher in the rural and urban TS than in HUNT3. The proportion reporting having had a troubled childhood was also significantly higher in both TS samples. The breakup of marriage or cohabitation during the last year was reported less frequently in both TS samples. Participants in the rural TS were more likely to report having ever been supressed or humiliated than the participants in HUNT3, but the reports of the urban TS participants were not significantly different. Few people reported having been in a life-threatening situation last year, and the differences were not significant.

Mental health factors related to mood were also examined through asking the same questions, with results shown in table 5 . The proportion reporting having been nervous or distressed during the last two weeks was significantly higher in the rural as well as the urban TS than in HUNT3. Fewer respondents reported not having felt safe and calm in the urban TS than in 
Table 5. Mental health (last 2 weeks) measured in the Nord-Trøndelag Health Study in 2006-08 (HUNT3) and the rural and the urban sample drawn for the telephone survey (TS). Differences significant beyond $5 \%$ are emphasized in italics.

\begin{tabular}{|c|c|c|c|c|c|c|}
\hline & \multicolumn{3}{|c|}{ Urban } & \multicolumn{3}{|c|}{ Rural } \\
\hline & $\mathrm{TS}$ & HUNT3 & & $\mathrm{TS}$ & HUNT3 & \\
\hline & $\mathrm{N}=400$ & $\mathrm{~N}=8788$ & $\mathrm{p}$ & $\mathrm{N}=200$ & $\mathrm{~N}=1412$ & $\mathrm{P}$ \\
\hline Safe and calm (no) & $7.9 \%$ & $11.7 \%$ & 0.021 & $10.3 \%$ & $12.7 \%$ & 0.353 \\
\hline Glad and optimistic (no) & $9.2 \%$ & $17.3 \%$ & 0.000 & $16.1 \%$ & $18.1 \%$ & 0.489 \\
\hline Nervous or distressed (yes) & $38.3 \%$ & $31.2 \%$ & 0.003 & $41.8 \%$ & $30.8 \%$ & 0.002 \\
\hline Bothered by anxiety (yes) & $12.5 \%$ & $13.4 \%$ & 0.599 & $16.3 \%$ & $14.9 \%$ & 0.613 \\
\hline Felt annoyed (yes) & $49.6 \%$ & $43.6 \%$ & 0.018 & $51.5 \%$ & $45.3 \%$ & 0.103 \\
\hline Felt down or depressed (yes) & $21.6 \%$ & $25.2 \%$ & 0.102 & $31.8 \%$ & $25.8 \%$ & 0.075 \\
\hline Felt lonely (yes) & $15.7 \%$ & $17.9 \%$ & 0.271 & $26.2 \%$ & $18.1 \%$ & 0.007 \\
\hline
\end{tabular}

Table 6. Attended cultural event (last 6 months), and perception of community quality measured in the NordTrøndelag Health Study in 2006-08 (HUNT3) and the rural and urban sample drawn for the telephone survey (TS). Differences significant beyond 5\% are emphasized in italics.

\begin{tabular}{|c|c|c|c|c|c|c|}
\hline & \multicolumn{3}{|c|}{ Urban } & \multicolumn{3}{|c|}{ Rural } \\
\hline & TS & HUNT3 & & TS & HUNT3 & \\
\hline & $\mathrm{N}=400$ & $\mathrm{~N}=8788$ & $\mathrm{p}$ & $\mathrm{N}=200$ & $\mathrm{~N}=1412$ & $\mathrm{P}$ \\
\hline Museum or art exhibition (yes) & $37.0 \%$ & $33.5 \%$ & 0.149 & $27.0 \%$ & $31.6 \%$ & 0.198 \\
\hline Concert, theatre, movie (yes) & $75.2 \%$ & $72.7 \%$ & 0.259 & $55.5 \%$ & $49.3 \%$ & 0.109 \\
\hline Church or house of worship (yes) & $45.0 \%$ & $56.4 \%$ & 0.000 & $54.0 \%$ & $54.2 \%$ & 0.968 \\
\hline Sports event (yes) & $49.5 \%$ & $50.4 \%$ & 0.721 & $49.0 \%$ & $45.7 \%$ & 0.399 \\
\hline Strong sense of community cohesion (agree) & $65.8 \%$ & $72.3 \%$ & 0.005 & $72.4 \%$ & $72.9 \%$ & 0.877 \\
\hline People thrive here (agree) & $89.0 \%$ & $91.1 \%$ & 0.146 & $91.5 \%$ & $90.4 \%$ & 0.620 \\
\hline
\end{tabular}

Table 7. Cultural activity participation (last 6 months) measured in the Nord-Trøndelag Health Study in 2006-08 (HUNT3) and the rural and urban sample drawn for the telephone survey (TS). Differences significant beyond $5 \%$ are emphasized in italics.

\begin{tabular}{|c|c|c|c|c|c|c|}
\hline & \multicolumn{3}{|c|}{ Urban } & \multicolumn{3}{|c|}{ Rural } \\
\hline & TS & HUNT3 & & TS & HUNT3 & \\
\hline & $\mathrm{N}=400$ & $\mathrm{~N}=8788$ & $\mathrm{p}$ & $\mathrm{N}=200$ & $\mathrm{~N}=1412$ & $\mathrm{P}$ \\
\hline Association activities (yes) & $46.1 \%$ & $43.7 \%$ & 0.345 & $40.7 \%$ & $34.5 \%$ & 0.097 \\
\hline Music, singing, theatre (yes) & $20.6 \%$ & $21.6 \%$ & 0.639 & $21.2 \%$ & $20.2 \%$ & 0.740 \\
\hline Outdoors activities (yes) & $85.9 \%$ & $83.7 \%$ & 0.259 & $75.8 \%$ & $81.0 \%$ & 0.094 \\
\hline Dancing (yes) & $22.5 \%$ & $38.3 \%$ & 0.000 & $21.2 \%$ & $36.8 \%$ & 0.000 \\
\hline Exercise, sports (yes) & $65.2 \%$ & $66.1 \%$ & 0.727 & $58.3 \%$ & $50.8 \%$ & 0.053 \\
\hline
\end{tabular}

HUNT3, with no significant deviation in the rural TS. A higher proportion of people had felt annoyed in the urban TS than in HUNT3, but there was no significant deviation in the rural TS. Fewer people reported not having felt glad and optimistic in the urban TS than in HUNT3, with no significant difference for the rural TS. A higher proportion of people in the rural TS reported having felt lonely in the last two weeks than in HUNT3, but the urban TS did not show a significant difference. The proportion reporting having been bothered by anxiety in the two TS samples did not deviate significantly from the HUNT3 results.

\section{Cultural participation and community}

The respondents were asked the same questions about their attendance at cultural events during the last six months, and questions relating to their perception of community quality, with results as shown in table 6 . The proportion reporting to have visited a church or house of worship was significantly less in the urban TS than in HUNT3. For participation at cultural events, including visiting an art exhibition or museum, having gone to the cinema, a concert or theatre, or having visited a sports event, there were no significant differences between HUNT3 results and the TS samples. Regarding community quality, the table shows the proportion of respondents who elected 'agree' to statements claiming there was a strong sense of community cohesion and that people thrive there. For community, there were no significant differences between the samples.

The same questions were asked about active participation in cultural activities during the last six months, with results as shown in table 7 . Respondents 


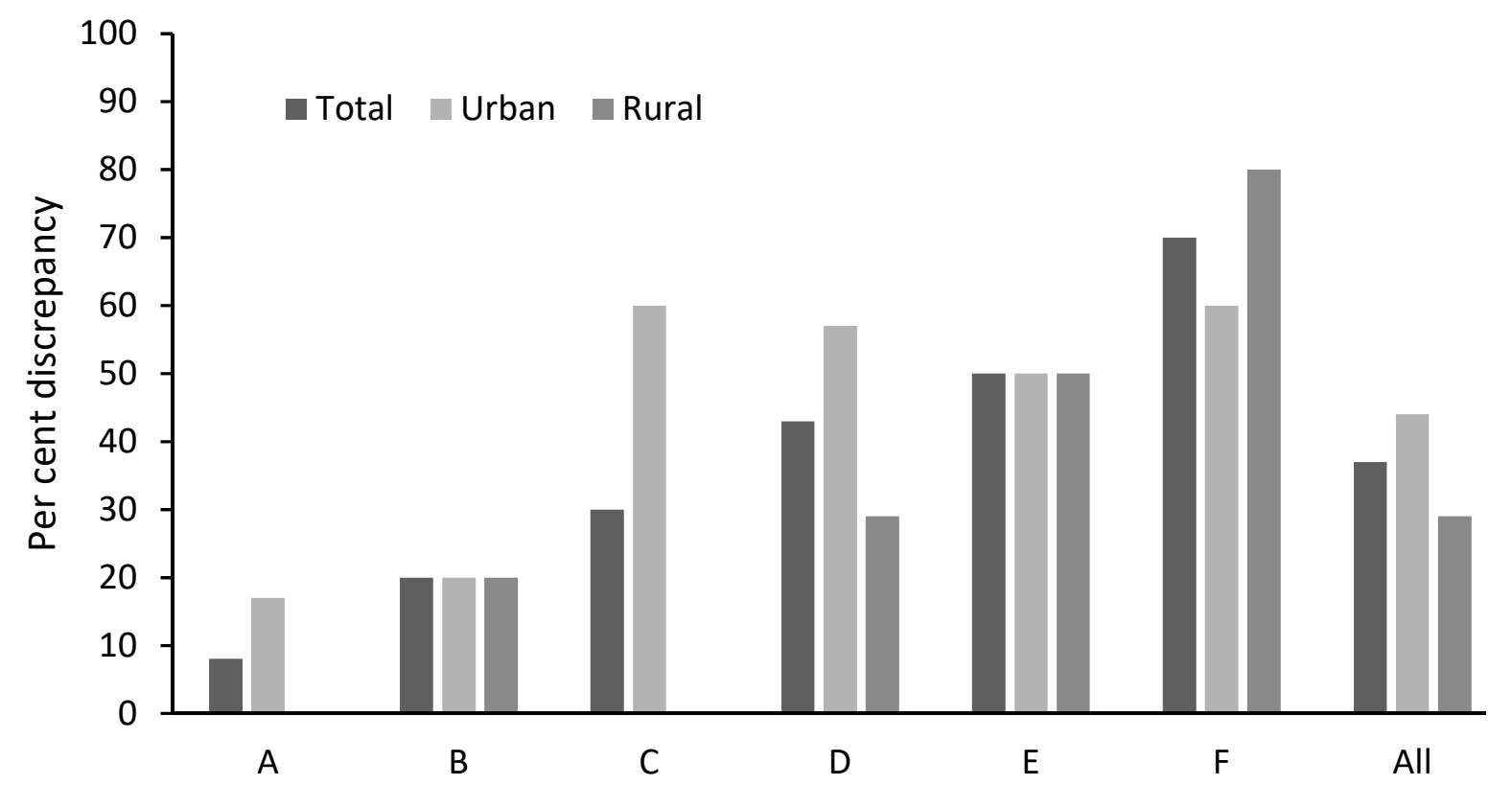

Figure 1. Per cent discrepancy between results in the telephone survey and the HUNT3 Study, total and stratified by rural and urban samples.

Categories: A: Attended cultural events + community; B: Participation in cultural activity; C: General health, pain and life satisfaction; D: Mental health; E: Lifestyle, behavioural and risk factors; F: Adverse life events; All: Overall

in the TS were significantly less likely to report dancing activities. For the proportion reporting having taken part in the activities of an association, having performed music, or engaged in singing, there were no significant differences between the samples. For the proportion engaged in outdoors activities and exercise and sports, there were no significant differences.

\section{Summary according to survey themes}

The comparison of results on 34 variables between the two HUNT3 samples and the two TS samples involved 68 chi square tests. Significant differences were found in 25 of these $(38 \%)$. Figure 1 shows a varying proportion of significantly diverging answers for the six themes in the surveys.

\section{DisCUSSION}

The comparison of results on 34 variables between the two HUNT3 samples and the two TS samples involved 68 chi square tests. We found significant differences in $25(38 \%)$ of these with a $5 \%$ level of significance. However, with the large number of tests the likelihood of rejecting a true null hypothesis increases (a Type I error). When we accounted for multiple testing by the Benjamini-Hochberg test at a $10 \%$ false discovery rate, the overall number of significant differences was reduced from 25 to $19(28 \%)$. The overall ability of the TS to replicate the HUNT3 results was thus only moderate. The comparability of the results appears to vary between themes examined through the two survey modes as shown in Figure 1. A higher proportion of significant deviations in the urban TS than in the rural TS can be ascribed to the difference in sample size.

\section{Strengths and limitations of this study}

The long time lag of nearly seven years, from JanuarySeptember 2007 to November 2013, between HUNT3 and the TS is a limitation, because changes over time can compete with mode effects related to social desirability and acquiescence in the explanation of differences between the survey results. We are fortunate to have knowledge of several trends across NordTrøndelag County based on time series data from HUNT, and these are likely to have continued to some extent between HUNT3 and the TS [15]. (Some results from HUNT and registry data for municipalities in Nord-Trøndelag have been made accessible to the public in an atlas available from https://vev.medisin.ntnu.no/atlas/voksenhunt/atlas.html .) Trends discussed further in relation to individual and groups of variables in the discussion of findings below. The sample sizes are small and unequal, as they were adapted to the funding capacity of a small and a larger municipality. A smaller sample size and multiple tests increase the risk of spurious findings, which is why the authors avoid basing the analysis on results for individual questions.

The substitution of non-respondents with new phone numbers from the initial sample, without making one or more additional call attempts, may have increased the risk of self-selection bias. This is not primarily due to the sampling procedure itself, but through the contribution to a high level of nonresponse in the TS. The availability and the willingness to respond to a phone call may vary according to a range of factors that are unevenly distributed. The associated risk of a skewed sample is increased through a procedure with a single 
attempt to call. Sending a letter in advance to introduce the study to the respondents could also have lowered the level of nonresponse further. The high level of nonresponse increases the risk of sampling error, where non-respondents may differ systematically from respondents with respect to other factors than those adjusted for by applying age and gender weights, including socioeconomic factors such as education, income or occupation, as well as health factors.

\section{Discussion of findings}

Regarding general health, pain and life satisfaction, agreement appears to be fair when the chi-square tests are tallied for subject themes, but when the direction of the significant deviations are taken under consideration, the results appear to be systematically skewed. There is less likelihood of reporting poor self-rated health or any long-standing limiting illness when interviewed on the phone. The significant differences for the urban sample may be lacking in the rural sample due to the smaller sample size. The differences appear to reflect a social desirability bias in telephone interviews regarding self-assessed health and well-being as previously reported by Feveile et al. [9]. For self-rated health, there was a significant decline in the proportion with poor self-reported health for the urban municipality from HUNT3 to the TS. The trend from HUNT2 to HUNT3 across Nord-Trøndelag was an increase in the proportion reporting good or very good health. There were some exceptions, as the latter trend was not present among the young adults, and reversed for women under 40 years [16]. Relating the finding for self-rated health to a broader trend would not be supported for the small town municipality, as the trend was not present in the HUNT data.

For lifestyle, behavioural and risk factors, the agreement was fair. The differences in the risk behaviours, reported smoking and frequent alcohol use, were small and do not show an accentuated social desirability bias. The HUNT3 data on obesity and overweight were gathered through clinical measurement and not through the questionnaire. The differences in overweight and obesity are thus examples of differences not between two modes of self-reporting, but rather between clinical measurement and selfreporting through telephone interview, where weight is underestimated and height overestimated in telephone interviews as previously described by Paccaud et al. [17]. There was a higher prevalence of high glucose and use of blood pressure medication in the TS than in HUNT3. This agrees with the authors' expectations of increasing trends based on knowledge of the trends across Nord-Trøndelag county from HUNT2 (199597) to HUNT3 (2006-08) [18,19]. From the overview of trends from the HUNT data [15], we would expect a continued decline in daily smoking, while the increase in total alcohol consumption as well as the increase in problematic alcohol consumption seen from HUNT2 to HUNT3 may have continued. Increases over time in the prevalence of known diabetes reported in interviews, and seen in registry data on the use of medication for diabetes, are associated with increases in overweight and obesity as important risk factors. Trends in smoking and high glucose were not confirmed through significant differences between HUNT3 and the TS. The use of blood pressure medication increased from HUNT1 (1984-86) to HUNT3 (200608). Increases in the use of blood pressure medication found in the small town and the rural municipalities may well reflect a continued trend.

Concerning adverse life events, comparability was poor. When the TS respondents were more likely to recall the death of a relative during the last year, but less likely to recall the breakup of marriage or cohabitation, the deviations appear to lack a clear direction. The TS came up with declines from HUNT3 in the proportion of respondents reporting break up in marriage or cohabitation in both samples. From registry data [20], there is a known moderate decline in divorces across the Nord-Trøndelag County in the period between HUNT3 and the TS. The association remains somewhat uncertain, as possible trends in breakup between cohabitants would not be registered.

The ability to replicate results on self-reported mental health factors was poor, with deviations lacking a clear direction. The exceptions were a relative stability in the reports on having been nervous or distressed, or having felt down or depressed during the last two weeks. A continued decrease in reported loneliness could be anticipated based on the noticeable decrease in reported loneliness from HUNT2 to HUNT3 for all groups except young men in Nord-Trøndelag County [16]. However, a significant increase in loneliness was found between HUNT3 and the TS for the rural municipality. Using the population size of the municipality as an indicator of centrality, Thorsen and Clausen [21] found only small differences in the proportion reporting loneliness in Norway.

There are indications of an increase in psychological disorders in data on sick leave and disability pensions, and in mental health problems from selfreported data from the level of living surveys of Statistics Norway after 2005. Negative scores have increased nationally among young females, and to a lesser extent among young males [22]. Skretting Lunde reported as early as 2001 of an increase in selfreported psychological symptoms in Norway. While the increase from 1985 to 1995 was influenced by the effects due to a shift in mode from phone interviews to paper questionnaires, the later increases were partly related to increased openness with regard to mental health [23]. In addition to changes in health, however, the increases in these indicators also reflect changes in how society is dealing with mental health [22]. Continued changes in attitudes towards mental health and adverse life experiences may make the themes less sensitive over time. This could lead to increased rapport, and a reduction in mode effects. 
The results for the above themes contrast with the reports about cultural participation, both as a spectator and as a performer, where the replication between the surveys was good. The same applies to community quality. The reports on cultural participation are considered the least sensitive theme in the interviews, and fall within the simple and factual, where Christensen et al. [7] found agreement across modes, rather than the subjective and complex. A low but stable national trend in churchgoing was reported by Gilhus Mykkeltvedt [24], based on European Social Survey data leading up to 2004. The trend may since have changed, as absolute numbers of attendances at mass on Sundays and holidays in the Nidaros Diocese in the Church of Norway declined by 15\% between 2006 and 2013, as reported by Statistics Norway [25]. The latter observation makes the significant decline in visits to a church or house of worship in the urban municipality appear plausible, even if this covers a larger region and is limited to the single largest religious community by membership.

Social desirability bias is a well-known problem in psychology and health services research, where methods involving interviewers often give results diverging from methods that rely on self-completion. Acquiescence, a tendency to agree, and the related tendency to give a socially desirable answer are also well known [26]. The presence of an interviewer tends to have a negative effect on report on sensitive issues $[7,8,10]$. There is a pattern where reports on uncomplicated factual subjects relating to cultural participation appear stable from HUNT3 to the TS when compared with other subjects. The reports on the more sensitive topics of mental health factors and adverse life events involve subjective assessments or more stressful recall and deviate significantly, but without a clear direction. With lifestyle, behavioural and risk factors, the results appear to capture the continuation of increasing trends for diabetes and blood pressure medication, while the reported tobacco and frequent alcohol use is relatively stable. Self-assessed health and well-being do not show the highest proportion of significant deviations, but there is, however, a clear tendency for more optimistic self-assessments when interviewed on the phone. The pressure towards giving a more socially desirable answer when interviewed on the phone thus appears to affect subjective self-assessments more than the more factual reports on risk factors.

A general decline in the response rates in health surveys, and mode effects are central concerns in the choice of mode, together with the cost effectiveness of data collection and processing. One may want to consider offering incentives for respondents as a countermeasure in order to improve response rates. However, in addition to considering the general issues including implications for representativeness, the improvements depend on contextual factors that need consideration. There are indications that the effect of incentives may be comparatively weak in Norway
[27]. The participation rates commonly achieved in telephone surveys have declined to the extent that nonresponse poses a serious threat to their validity. Phone coverage, initially through landlines, remained partial into the $1980 \mathrm{~s}$, but became near universal so that phone interviews could become a leading mode of data collection for a period of several decades [5]. The pace of change in access to communication technology and communication habits has increased since then. From the starting point of this study in 2006 to 2017 , access to the internet has become near universal in Norway, with an increase from $79 \%$ to $98 \%$. Access to a smartphone has become widespread, with $91 \%$ in 2017, and may soon become near universal [28].

Modes relying on written responses, through traditional pen-and-paper questionnaires and web-based questionnaires, may be preferable due to the known interviewer effects influenced by sensitivity in health surveys. A mailed paper questionnaire still tends to return the highest response rate in recent studies, but the gains over choices including web questionnaires used either alone, or offered as an option in addition to pen-and pencil, can be marginal (i. e. within 3\%) as reported by Hohwü et al. [29]. A test of modes in Denmark achieved a response rate of $53 \%$ with two reminders and an incentive offered in the web mode. The cost per respondent can be $40 \%$ [30] to $50 \%$ [29] lower in web surveys when compared to mailed questionnaires, and the results are usually more rapidly available. Given the rate of adoption of technology, web-based questionnaires may be an alternative to paper questionnaires in future surveys of public health in Nordic contexts [29].

\section{CONCLUSION}

With a moderate overall ability of the TS to replicate the HUNT3 comprehensive health survey results, the reliability of the TS is moderate. The comparability of the data differs between themes. The difference can be ascribed to mode effects, and to some extent the time lag between the surveys. Based on the number of significant deviations in chi-square tests, replicability on issues that may be more embarrassing or stressful to recall appears to be poorer. When the direction in the deviations is considered, the more subjective selfassessed health and well-being appears to be skewed, with more positive scores in the TS. The best replication is found for cultural participation, which involves less subjective assessment and is less sensitive than the health and risk factors. It is reasonable to conclude that an interviewer effect is present in the TS, with different effects according to subject themes. The degree of privacy enjoyed by the informant while answering questions is likely to affect acquiescence and social desirability bias. The use of a questionnaire through mail or web to provide overviews of public health for municipalities should be considered as an alternative to telephone interviews. 


\section{ACKNOWLEDGEMENTS}

The research was undertaken as a part of Political decisions on determinants - Research Area / Politiska beslut på bestämningsfaktorer for hälsa och tilväkst (PODD-RA), project N30441-24-12, funded through the programme Interreg Sweden-Norway in the EU European Regional Development Fund. The Norwegian component was funded by the Norwegian government (InterReg), Nord-Trøndelag
County, Sør-Trøndelag County Authority, Sentio Research Norge AS and HUNT Research Centre at the Norwegian University of Science and Technology. The project was managed by Nord-Trøndelag County (Norway) and Region Jämtland Härjedalen (Sweden).

Sentio Research Norge AS participated in the PODD-RA research project, organised and conducted the interviews in the TS.

\section{REFERENCES}

1. Report no. 47 to the Storting (2008-2009). Samhandlingsreformen. Rett behandling - på rett sted - til rett tid. (The coordination reform - Proper treatment - at the right place and the right time). Oslo: Helse- og omsorgsdepartementet; 2009.

2. Lov om folkehelsearbeid (folkehelseloven). LOV - 2011 - 06 - 24 - 29.

3. Forskrift om oversikt over folkehelsen. FOR - $2011-06-28-692$.

4. Report no. 34 to the Storting (2012-2013). Folkehelsemeldingen. God helse - felles ansvar. Oslo: Helse- og omsorgsdepartementet; 2013.

5. de Leeuw E, Berzelak N: Survey mode or survey modes? In: The Sage handbook of survey methodology. Edited by Wolf C, Joye D, Smith TW, Fu Y-c. United Kingdom: Sage Publications; 2017: 142-156.

6. Brøgger J, Bakke P, Eide GE, Gulsvik A: Comparison of telephone and postal survey modes on respiratory symptoms and risk factors. Am J Epidemiol 2002, 155(6):572-576

7. Christensen A, Ekholm O, Glümer C, Juel K: Effect of survey mode on response patterns: comparison of face-to-face and self-administered modes in health surveys. Eur J Public Health 2013, 24(2):327-332.

8. Tipping S, Hope S, Pickering K, Erens B, Roth MA, Mindell JS: The effect of mode and context on survey results: Analysis of data from the Health Survey for England 2006 and the Boost Survey for London. BMC Med Res Methodol 2010, 10(84).

9. Feveile $\mathrm{H}$, Olsen O, Hogh A: A randomized trial of mailed questionnaires versus telephone interviews: Response patterns in a survey. BMC Med Res Methodol 2007, 7(27).

10. Tourangeau R, Smith TW: Asking sensitive questions: The impact of data collection mode, question format, and question context. Public Opin Q 1996, 60(2):275-304.

11. Hoebel J, von der Lippe E, Lange C, Ziese T: Mode differences in a mixed mode health interview survey among adults. Arch Public Health 2014, 72(46):1-12.

12. Krokstad S, Langhammer A, Hveem K, Holmen TL, Midthjell K, Stene TR, Bratberg G, Heggland J, Holmen J: Cohort Profile: the HUNT Study, Norway. Int J Epidemiol 2013, 42(4):968-977.

13. Jacobsen BK, Eggen AE, Mathiesen EB, Wilsgaard T, Njølstad I: Cohort profile: The Tromsø Study. Int J Epidemiol 2012, 41(4):961-967.

14. Langhammer A, Krokstad S, Romundstad P, Heggland J, Holmen J: The HUNT study: participation is associated with survival and depends on socioeconomic status, diseases and symptoms. BMC Med Res Methodol 2012, 12:143.

15. Krokstad S, Knudtsen MS (eds): Folkehelse i endring. Helseundersøkelsen Nord-Trøndelag. HUNT 1 (198486) - HUNT 2 (1995-97) - HUNT 3 (2006-08) / Public health development. The HUNT Study, Norway. HUNT 1 (1984-86) - HUNT 2 (1995-97) - HUNT 3 (2006-08). Levanger: HUNT Research Centre, NTNU Norwegian University of Science and Technology; 2011.

16. Krokstad S, Thoen H: Psykisk helse og livskvalitet. In: Folkehelse i endring Helseundersøkelsen NordTrøndelag HUNT 1 (1984-86) - HUNT 2 (1995-97) - HUNT 3 (2006-08) Public health development The HUNT Study, Norway HUNT 1 (1984-86) - HUNT 2 (1995-97) - HUNT 3 (2006-08). Edited by Krokstad S, Knudtsen MS. Levanger: HUNT Research Centre; 2011: 108-117.

17. Paccaud F, Wietlisbach V, Rickenbach M: Body mass index: comparing mean values and prevalence rates from telephone and examination surveys. Rev Epidemiol Sante Publique 2001, 49(1):33-40.

18. Holmen J, Thoen H: Somatisk Helse. In: Folkehelse i endring Helseundersøkelsen Nord-Trøndelag HUNT 1 (1984-86) - HUNT 2 (1995-97) - HUNT 3 (2006-08) / Public health development The HUNT Study, Norway HUNT 1 (1984-86) - HUNT 2 (1995-97) - HUNT 3 (2006-08). Edited by Krokstad S, Knudtsen MS. Levanger: HUNT Research Centre, NTNU- Norwegian University of Science and Technology; 2011: 17-35.

19. Midthjell K: Diabetes. In: Folkehelse i endring Helseundersøkelsen Nord-Trøndelag HUNT 1 (1984-86) HUNT 2 (1995-97) - HUNT 3 (2006-08) / Public health development The HUNT Study, Norway HUNT 1 (1984-86) - HUNT 2 (1995-97) - HUNT 3 (2006-08). Edited by Krokstad S, Knudtsen MS. Levanger: HUNT Research Centre, NTNU- Norwegian University of Science and Technology; 2011: 64-69.

20. Statistics Norway. Tabell 09660: Skilsmisser og separasjoner (K) 1966-2017. [https://www.ssb.no/statbank/table/09660] (accessed 10.11.18). 
21. Thorsen K, Clausen S-E: Hvem er de ensomme? Samfunnsspeilet 2009(1):74-78.

22. Reneflot A, Aarø LE, Aase H, Reichborn-Kjennerud T, Tambs K, Øverland S: Psykisk helse i Norge. Oslo: Folkehelseinstituttet; 2018.

23. Skretting Lunde E: Større åpenhet om psykisk helse. Samfunnsspeilet 2006(5):21-29.

24. Gilhus Mykkeltvedt A: European Social Survey (ESS). Få nordmenn i kirken, men ikke færre enn før. NSDnytt 2006(1):[no pagination].

25. Statistics Norway. Tabell 06929: Den norske kirke (DNK). Medlemmer og tilhørige, kirkelige handlinger og gudstjenester, etter bispedømme 2005-2017. [https://www.ssb.no/statbank/table/06929] (accessed 10.11.18).

26. Robling MR, Ingledew DK, Greene G, Sayers A, Shaw C, Sander L, Russell IT, Williams JG, Hood K: Applying an extended theoretical framework for data collection mode to health services research. BMC Health Services Res 2010, 10:180.

27. Sthli ME, Joye D: Incentives as a Possible Measure to Increase Response Rates. In: The SAGE Handbook of Survey Methodology. Edited by Wolf C, Joye D, Smith TW, Yang-chihFu: SAGE Publications; 2017: 425440.

28. Statistics Norway. Tabell 05244: Andel som har tilgang til ulike medier og elektroniske tilbud i hjemmet (prosent) 1991-2017. [https://www.ssb.no/statbank/table/05244] (accessed 10.11.18).

29. Hohwü L, Lyshol H, Gissler M, Jonsson SH, Petzold M, Obel C: Web-based versus traditional paper questionnaires: A mixed-mode survey with a Nordic perspective. J Med Internet Res 2013, 15(8):e173.

30. McMaster HS, LeardMann CA, Speigle S, Dillman DA: An experimental comparison of web-push vs. paperonly survey procedures for conducting an in-depth health survey of military spouses. BMC Med Res Methodol 2017, 17(73):1-9.

\section{APPENDIX. SPøRRESKJEMA PODDRA. HELSEDATA-PILOTEN}

\section{INTRODUKSJON:}

Hei,

Jeg ringer fra SENTIO på uppdrag av Nord-Trøndelags fylkeskommune/Sør-Trøndelags fylkeskommune og prosjektet PODD-RA i Interreg Sverige-Norge programmet. Stortinget besluttet å innføre Folkehelseloven fra 2011. Den pålegger kommunene å ha oversikt over innbyggernes helse. Norges teknisk naturvitenskapelige universitet - NTNU og Helseundersøkelsen i Nord-Trøndelag - HUNT - gjennomfører nå en test om det lar seg gjøre å samle inn data om innbyggernes helse gjennom telefonintervju. Dette er altså et forsøk vi håper du gir ditt bidrag til ved å la oss få stille deg noen spørsmål om tema knyttet til fysisk og psykisk helse og noen spørsmål knyttet til bakgrunn og livsstil. Ingen svar er riktige eller gale. Vi trenger dine ærlige svar om din egen helse. Med din hjelp kan vi komme et skritt nærmere en bedre helse for innbyggerne i kommunene eller «sett inn navn på kommune». Du er selvfølgelig helt anonym $\mathrm{i}$ henhold til retningslinjer fra Datatilsynet og personvernet. Intervjuet tar ca 15 minutter, og jeg vil understreke at det frivillig å delta. Noen spørsmål kan nok oppfattes som nærgående, men du kan velge om du vil svare på de enkelte spørsmålene eller ikke. Du kan også når som helst under intervjuet trekke deg. Det du tidligere har svart blir da slettet. Dersom du skulle ha behov for å snakke med en helseperson etter intervjuet, kan du få et telefonnummer du kan ringe.

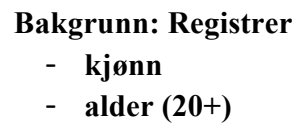

\section{DEL 1. FATTIGDOM OG BAKGRUNN/HOVEDVARIABLER}

1. Hvor mange personer er det $i$ husstanden din som er 16 år eller eldre? Noter antall
2. Og hvor mange personer er det $i$ husstanden din som er under 16 år? Noter antall

3. Hvor stor tror du den samlede netto (Utbetalt inntekt etter skattefradrag) inntekten for alle (hele) $i$ husholdningen din er i måneden? Vi tenker da på den totale inntekten etter at skatt er trukket for alle medlemmene. Med inntekt tenker vi både på lønn for arbeid, trygdeytelser osv. Altså den totale summen husstanden har å fordele på alle faste og variable utgifter hver måned etter skatt.

a. Skriv inn eksakt beløp

b. (IKKE LES) Vet ikke/vil ikke svare

\section{Hva er din høyeste fullførte utdanning?}

a. Ubesvart

b. Grunnskole/folkeskole/realskole

c. Videregående skole (1-3 år etter grunnskole)

d. Universitet/høyskole (1-3 år etter videregående skole)

e. Universitet/høyskole (4 år eller mer etter videregående skole)

f. (IKKE LES) Vet ikke/vil ikke svare

5. Hvordan er helsa di nå? Er den;
a. Dårlig
b. Ikke helt god
c. God
d. Svært god
e. (IKKE LES) Vet ikke/vil ikke svare

6. På en skala fra 1 til 5 der $1=$ =svært misfornøyd, og $5=$ =svært fornøyd, hvor fornøyd totalt sett er du med din kommune som en plass å bo og leve i?

a. Svært misfornøyd

b. Misfornøyd

c. Både og

d. Fornøyd

e. Svært fornøyd

f. (IKKE LES) Vet ikke/vil ikke svare 
7. Har det i løpet av det siste året hendt at husholdningen har hatt vansker med å klare de løpende utgifter til mat, transport, bolig og liknende? LES OM NODVENDIG
a. Ja, ofte
b. Ja, av og til
c. Ja, en sjelden gang
d. Nei, aldri
e. (IKKE LES) Vet ikke/vil ikke svare

\section{DEL 2. DELTAKELSE I SAMFUNNET OG LOKALSAMFUNNET}

8. Hvor mange ganger har du i lopet av de siste 6 måneder vært på: LES OPP

a. Museum eller kunstutstilling

b. Konsert, teater eller kino

c. Kirke eller bedehus

d. Idrettsarrangement

- Mer enn 3 ganger i måneden

- 1-3 ganger hver måned

- 1-6 ganger siste 6 mnd

- Aldri

- (IKKE LES) Vet ikke/vil ikke svare

9. Hvor mange ganger har du i løpet av de siste 6 måneder selv drevet med: LES OPP

a. Foreningsvirksomhet

b. Musikk, sang, teater

c. Friluftsliv

d. Dans

e. Trening, idrett

- Mer enn 3 ganger i måneden

- 1-3 ganger hver måned

- 1-5 ganger siste 5 mnd

- Aldri

- (IKKE LES) Vet ikke/vil ikke svare

10. I hvilken grad føler du at du har innflytelse på kommunale beslutninger? Er det;

a. I svært stor grad

b. I noen grad

c. Både og

d. I liten grad

e. I svært liten grad

f. (IKKE LES) Vet ikke/vil ikke svare

11. Så noen påstander om ditt nærmiljø, dvs. nabolaget eller grenda du bor i. I hvilken grad er du enig eller uenig i følgende påstander: LES OPP

a. Jeg føler et sterkt fellesskap med de som bor her

b. Man kan ikke stole på hverandre her

c. Folk trives godt her
A. Helt enig
B. Delvis enig
C. Verken enig eller uenig
D. Delvis uenig
E. Helt uenig
F. (IKKE LES) Vet ikke/vil ikke svare

12. Når du tenker på barndommen din/oppveksten din, vil du beskrive den som LES OPP:

a. Svært god

b. God

c. Middels

d. Vanskelig

e. Svært vanskelig

f. (IKKE LES) Vet ikke / vil ikke svare

\section{DEL 3. LIVSSTIL}

13. Hvor ofte spiser du grønnsaker, frukt eller bær?

a. Hver dag

b. Ikke hver dag

c. (IKKE LES) Vet ikke/vil ikke svare

14. Trener eller mosjonerer du en halvtime eller mer hver dag?
a. Ja
b. Nei
c. (IKKE LES) Vet ikke/vil ikke svare

15. Har du noen gang fått påvist høyt blodsukker (f.eks. ved helsekontroller, ved graviditet etc.)?
a. Nei
b. Ja
c. (IKKE LES) Vet ikke/vil ikke svare

16. Har noen i din familie fått diabetes? Flere svar mulig a. Nei

b. Ja: Jeg selv har fătt diabetes

c. Ja: besteforeldre, tante/onkel eller søskenbarn (men ikke foreldre, søsken eller egne barn) MULTI

d. Ja: biologiske foreldre, søsken eller egne barn MULTI

e. (IKKE LES) Vet ikke/vil ikke svare

17. Så har vi et par spørsmål kun av statistisk interesse. TIL INTERVJUER: Om respondenten ikke er helt sikker så be om et anslag

a. Hva er din vekt?

i. Oppgi antall kilo

ii. (IKKE LES) Vet ikke/vil ikke svare

b. Og hvor høy er du

i. Oppgi antall $\mathrm{cm}$

ii. (IKKE LES) Vet ikke/vil ikke svare

18. Har du noen gang brukt blodtrykksenkende medisiner?

a. Nei

b. Ja

c. (IKKE LES) Vet ikke/vil ikke svare

i. Hvis JA: Bruker du medisin for høy blodtrykk NÅ?

1. Ja

2. Nei

19. Røyker du daglig?

a. Ja

b. Nei

c. (IKKE LES) Vet ikke/vil ikke svare

20. Omtrent hvor ofte har du i løpet av de siste 12 måneder drukket alkohol? (Regn ikke med lettøl)

a. 4-7 ganger pr uke

b. 2-3 ganger pr uke

c. Ca 1 gang pr uke

d. Ca 1 gang pr måned

e. Noen få ganger pr år

f.Ingen ganger siste år

g. Aldri drukket alkohol

h. (IKKE LES) Vet ikke/vil ikke svare

\section{DEL 4. FYSISK HELSE}

21. Har du kroppslige smerter nå som har vart mer enn 6 måneder?

a. Ja

b. Nei

c. (IKKE LES) Vet ikke/vil ikke svare 
22. Hvor sterke kroppslige smerter har du hatt i løpet av de siste 4 uker? Har du hatt ...

LES OPP KUN ETT SVAR MULIG

a. Ingen smerter

b. Meget svake smerter

c. Svake smerter

d. Moderate smerter

e. Sterke smerter

f. Meget sterke smerter

g. (IKKE LES) Vet ikke/vil ikke svare

23. Har du noen langvarig (minst 1 år) sykdom, skade eller lidelse av fysisk eller psykisk art som nedsetter dine funksjoner i det daglige liv?
1. Ja
2. Nei

\section{Hvis ja:}

24. Jeg vil nå lese opp noen funksjonshemninger og be deg ta stilling til om du er mye nedsatt på dette området, middels nedsatt, litt nedsatt eller ikke nedsatt i det hele tatt:
a. Bevegelseshemning
b. Nedsatt syn
c. Nedsatt hørsel
d. Funksjonshemning pga kroppslig sykdom
e. Funksjonshemning pga psykisk sykdom

Svaralternativer for hver:
a. Litt nedsatt
b. Middels nedsatt
c. Mye nedsatt
d. (IKKE LES) Vet ikke/vil ikke svare

Nå kommer vi til noen spørsmål som kan virke mer nærgående, og du kan velge om du vil svare eller ikke.

\section{DEL 5. PSYKISK HELSE}

25. Jeg vil nå lese opp noen sinnsstemninger og be deg ta stilling til hvor ofte du har vært i disse stemningene de siste 2 ukene. LES OPP:
a. Trygg og rolig
b. Glad og optimistisk
c. Nervøs og urolig
d. Plaget av angst
e. Irritabel
f. Nedfor/deprimert
g. Ensom

\section{Svaralternativer:}

Nei ikke i det heletatt/Litt/En god del/ Svært mye/(IKKE

LES) Vet ikke/vil ikke svare

26. Så ønsker vi å spørre om det har vært noen alvorlige livshendelser hos deg de siste 12 måneder. Svar Ja eller Nei på følgende spørsmål:

a. Har det vært dødsfall i nær familie? Da tenker vi på barn, ektefelle/samboer, søsken eller foreldre.

b. Har du vært i overhengende livsfare pga. alvorlig ulykke, katastrofe, voldssituasjon eller krig?

c. Har du hatt samlivsbrudd i ekteskap eller i lengre samboerforhold?

$-\mathrm{Ja}$

$-\mathrm{Nei}$

- (IKKE LES) Vet ikke/vil ikke svare

27. Filter: Hvis Ja i ett eller flere av spørsmålet over. I hvilken grad har du hatt reaksjoner på dette de siste 7 dager? Vil du si i høy grad, i moderat grad, litt eller ikke i det hele tatt?
a. I høy grad
b. I moderat grad
c. Litt
d. Ikke i det hele tatt
e. (IKKE LES) Vet ikke/vil ikke svare

28. Har du noen gang i livet opplevd at noen over lengre tid har forsokt å kue, fornedre eller ydmyke deg?
a. Ja
b. Nei
c. (IKKE LES) Vet ikke/vil ikke svare

29. Når du tenker på hvordan du har det for tida. I hvilken grad er du fornøyd med tilværelsen? Er du... LES OPP
a. Svært fornøyd
b. Meget fornøyd
c. Ganske fornøyd
d. Både og
e. Nokså misfornøyd
f. Meget misfornøyd
g. Svært misfornøyd
h. (IKKE LES) Vet ikke/vil ikke svare

Det var det vi ønsket å spørre om. Dersom du i ettertid trenger å snakke med en helseperson, kan du ringe telefonnummer

Takk skal du ha! 